\title{
POTENTIAL OF HUNTING TOURISM IN THE MIDDLE BANAT
}

\author{
Milutin Mrǩ̌a ${ }^{*}$, Novi Sad Business School, Novi Sad
}

\begin{abstract}
The aim of this paper is to present the potential of hunting tourism in the Middle Banat in the promotion and advancement of this particular form of tourism activities. Hunting is one of the most economically important form of tourism activities because in addition to the regular services of transportation, lodging and hunting licenses, tourists pay for a hit-and-miss), a meat and a trophy. With the aim of presenting the potential in a quality manner, special attention will be paid to hunting clubs, hunting grounds and accommodation facilities, which are in addition to the human sector, the most important factor in hunting tourism.
\end{abstract}

Key words: Middle Banat, hunting, tourism.

JEL classification: $Q 10,013$

\section{POTENCIJALI LOVNOG TURIZMA U SREDNJEM BANATU}

Sažetak: Cilj rada je da predstavi potencijale lovnog turizma u Srednjem Banatu u cilju promocije i unapređenja ovog posebnog oblika turističkih aktivnosti. Lovni turizam je jedan od ekonomski najznačajnijih oblika turističke aktivnosti, jer pored redovnih usluga prevoza, smeštaja i dozvola za lov, turisti plaćaju za odstrel ( $i$ za promašaj), za meso $i$ za trofej. U cilju kvalitetnijeg predstavljanja potencijala posebna pažnja biće posvećena lovačkim udruženjima, lovištima i smeštajnim objektima, koji su pored ljudskog sektora, najvažniji činilac lovne turističke ponude.

Ključne reči: Srednji Banat, lov, turizam.

\section{INTRODUCTION}

Tourism is a specific form of human activity, free-time activity and leisure and satisfaction of recreational and social needs, and no human activity, and the activity in general is dependent on the properties of the environment as much as tourism and recreation are. Recreation is a special type of tourist activity that

\footnotetext{
*mmrksa@gmail.com
} 
aims to revitalize a function of the organism, and it is very important, if not a crucial factor for the quality of the environment. This especially applies to recreational activities and outdoor sports which have been linked to environmental quality.

The specificity of hunting tourism activities in relation to other forms of tourism lies in the fact that for its performance, the existence of certain available funds of one or more species of wildlife in a natural setting which is adequately adjusted (equipped and stocked with adequate facilities, resources, devices, etc...) is a necessity to obtain the safe and successful hunt season. Thanks to the realization of profits, which are primarily realized from the collection of the shot game (and especially hunting trophies), hunting is a specific form of tourism, which directly consumes natural resources (wildlife), which is not the case with most other forms of tourism.

In addition to environmental and economic aspects, hunting also has a health (recreation and active relaxation in a healthy natural environment), cultural (behavior in the spirit of hunting moral and the code of hunters ethics, artistic creativity inspired by motifs of nature, wildlife and hunting) and educational meaning (education of not only hunters, but the broader population of young people and adults in the spirit of understanding, cultivation and protection of wildlife, nature conservation and preservation of biodiversity). The importance of hunting is reflected in its contribution to the development of other activities including: agriculture and forestry (encouraging the growth of those types of crops that are used for feeding the game, tree planting, protection of forest stands and crops from damage done by wildlife, etc.), tourism (through the activity of hunting tourism), hospitality (expanding restaurant network and use of game meat in their cuisine), commerce (selling the items of meat, skin, fur, horns, tusks, bones of wildlife, etc.), and other industries, as are travel and telecommunications industry, and also certain industries (for example those involved in the production of hunting weapons, ammunition, equipment, clothing, souvenirs, etc.). The special significance of hunting lies in the fact that modern hunting is conceived and constituted so that it is in the function of sustainable development. It means that hunting which represents a complex activity of managing wildlife populations for their protection, breeding (artificial production, population, health care, nutrition), hunting and rational use, as well as maintaining and improving the habitat conditions in hunting grounds, not only provides the optimum reproducibility of the existing wildlife populations according to the potentials of their habitats (biological and economic capacity of a hunting ground), but also aims to prevent and repair any damage wildlife may cause in a given ecosystem or biotope. Therefore, it does not significantly distort biological diversity and can be characterized as sustainable hunting (Prentović, Kurjački, \& Cvijanović, 2012). 


\section{METHODOLOGY}

For the purpose of this research, methods used in the field are: the analysis of literature and other documents in this area, as well as basic scientific and logical designation process analysis, synthesis, induction, deduction and comparison. The research is done for the purpose of objective consideration of the potential of hunting tourism in the Middle Banat in order to be able to ascertain the current status, spot flaws and problems, but also to create a basis for future planning and development.

\section{BASIC CHARACTERISTICS OF THE MIDDLE BANAT}

The Middle Banat is a central part of the eponymous area of Vojvodina and includes the town of Zrenjanin, the municipality of Novi Bečej, Nova Crnja, Žitište and Sečanj. The area, for the most part, covers the loess soil which caused relief forms related to the forest. The most significant relief mezzo part is the Novi Bečej-Zrenjanin loess terrace. Significant landforms are the Tamiš loess plateau (plateau) and alluvial plains of rivers (Mrkša, 2009).

The climatic characteristics of the study area are reflected in the following elements and values. January is the only month with a negative mean monthly air temperature $\left(-1.0^{\circ} \mathrm{C}\right)$, while all other months have positive mean monthly air temperatures, in July and August the highest value being $21.5^{\circ} \mathrm{C}$ and 21.0 ${ }^{\circ} \mathrm{C}$, respectively. Relative air temperature shows a disparity in the distribution of heat throughout the year. Thus, the lowest relative temperature of the month occurs in January, whereas it reaches its maximum in July. The lowest mean minimum temperature occurs during the winter months and a maximum value in July and August. The amplitude between minimum air temperatures ranges from $20.6^{\circ} \mathrm{C}$ to $6.1^{\circ} \mathrm{C}$ (Lazić, \& Pavić, 2003). The most frequent winds blow from the south-east and north-west direction, and rarely east and northeast. A monthly minimum average and annual relative humidity are observed in summer and the highest in winter. The least monthly average relative humidity is observed in July and the highest in December. The months with low values are: May, June and August, and with high values: January, February and November. The largest clouds are observed in the lazy months of July and August, and in winter, January and December. Insolation has the highest values in July and August and lowest in December and January. The greatest rainfall appears in June and the lowest during the month of January.

Groundwater is mainly characterized by considerable diversity, relatively easy accessibility and adequate richness, and therefore the use of groundwater is of major importance for the lives of people in this area (Bogdanović, \& Marković, 2005). Surface waters are represented through the rivers, lakes and the Hydro System Danube-Tisa-Danube (DTD). The Tisa is the largest and the most 
significant international river in the Middle Banat. The Tisza water sector largely provides the amenity and navigation, and, to some extent, it is used in energy, fishing and for other purposes. Boating currently has regional importance. Begej is the largest tributary of the Tisza River. Begej arises from two branches that connect with Klek, namely: the Stari Begej and Begej channel which is also called the Fairway Begej. The Begej channel has always been an important waterway, since it connects two important settlements in Timisoara (Romania) and Zrenjanin (Serbia). The Tamiš river originates in Romania, on the mountain Seminal vesicles and flows into the Danube at Pančevo. The Tamiš river flows through our country's southeast, except for the part where it joins the channel Novi Bečej-Bačka Palanka, in a southwest direction. Banat is known for its many lakes, ponds and wetlands. Most of them are man-made lakes, ponds and oxbow ponds. The most important lakes of the Middle Banat are Kopovo, Ostrovo, Rusanda, Okanj, The "Ečka" fish-pond and "Sutjeska". The significance of the Danube-Tisa-Danube is very large, resulting in the sixties, the period in which the water community in the territory of Bačka and Banat joined the newly formed hydro system. This hydro system on the Banat area includes primary ducts and channels of lower rank.

A special Nature Reserve "Slano Kopovo" is located in the municipality of Novi Bečej, north-east of the homonymous municipality center of which is located about $5 \mathrm{~km}$. By the regulation of the Government of the Republic of Serbia, in 2001, Slano Kopovo was declared for special nature reserve. The reserve covers an area of 976 hectares and was established by the three-tier protection regime. The Zone I degree of protection covers the area of $217 \mathrm{ha}$. In this zone, the use of natural resources is prohibited and it excludes all forms of space utilization and activities other than scientific research and controlled education. The Zone II degree of protection covers the area of 220 ha. This zone is limited and it subsumes a strictly controlled use of natural resources. Activities in the area can be done to an extent that allows the improvement of the condition and presentation of natural goods without prejudice to its primary values. The Zone III level of protection covers the area of 539 ha. This zone was established as the selective and limited use of natural resources and controlled interventions and activities in the area, in line with the functions of protected natural resource or linked to inherited traditional forms of business activity and housing, including tourism-related construction (Mrkša, 2008).

A special Nature Reserve "Stari Begej-Carska bara" is located southwest of Zrenjanin. It is located on the alluvial plain Begej and Tisza and has the form of the Latin letter "S". The protected area is located in the alluvial plain between the Tisza and Begej, south of Ečka, Stajićevo and Luke and the villages north of Perlez, in the municipality of Zrenjanin. The first protection was proclaimed in 1955, when "Vojtina mlaka" because of its natural beauty has been protected 
under the Law on the Protection of Cultural Monuments and Natural Rarities. The reserve area is 1,676 ha. A space on the first level of protection is the area of 703.7 ha and occupies $42 \%$ of the reserve, a part of the second level of protection is the area of 371.8 ha and occupies $22.2 \%$ of the territory and the area of the third degree of protection occupies 600.5 hectares and covers $35.8 \%$ reserve space (Group of authors, 1993). In order to protect the area, certain types of protection that should be respected are defined: the Zone I degree of protection allowed the scientific work, controlled forms of education, control, monitoring plant and animal species. Conditionally permitted activities include sanitary and regulatory catch wild pigs, deer and sanitary fishing. The prohibited activities include reforestation of grassland areas, draining of marsh land, commercial and sport fishing, all types of hunting, as well as changes to the prescribed water regime. The Zone II degree of protection allowed scientific research, controlled lawn mowing, the use of cane and reeds, sanitary logging, logging of native forests and reforestation of native species, hunting of appropriate, fishing, beekeeping, movement of vessels that do not pollute the environment, sanitation hunting, fishing and selective fishing. The prohibited activities include: reforestation of grassland area, converting the marshy marsh ecosystems to terrestrial, statutory changes to the water regime, the introduction of alien plant and animal species, commercial fishing, hunting for commercial purposes and the use of boats for sport fishing. The Zone III level of protection allowed is limited to animal husbandry and the use of cane for commercial purposes, limited use of forests, forest products and the collection of medicinal plants, selective production, controlled tourism and purposeful construction of tourist facilities. The prohibited activities include water pollution, pesticide use, a forestation of non-native species, and so on.

\section{ACCOMMODATION FACILITIES}

When presenting restaurants of the Middle Banat, there will be listed only those that are in operation (except those that are currently closed due to renovations, additions, privatization, etc.) with basic features.

Hotel "Vojvodina" (****) is the largest hotel in Zrenjanin and is located in the center. Recently privatized and renovated, the new edition offers accommodation in 92 accommodation units and 76 modern rooms, out of which 35 with a double bed and 41 doubles, 11 suites and 4 business suites. All rooms are equipped to the latest standards (mini bar, bathroom, TV, telephone, the Internet, etc.) and there are separate floors for smokers and non-smokers. The hotel also includes a restaurant with a total of 400 seats, a bar, a business center with 260 seats, two smaller conference halls with 30 seats, and a spa.

Banja "Rusanda" (**) in Melenci is located on the shores of the Lake Rusanda and has five hotels - the pavilion with a total capacity of 150 beds. The spa BUSINESS SCHOOL, 1/2015, $58-67$ 
complex also operates a special hospital for the treatment of paraplegia and hemiplegia, restaurant, patisserie and summer terrace.

"Ečka" (**) is built in the English style in the period from 1816 to 1820. Today, it has turned into a typical small hotel, located in the park. The complex has 14 rooms and 3 suites, also reflects, ballroom, a summer terrace and a parking. The inner side of the complex is a park with trails for walking and benches.

Hotel "Sibila" (**) Carska Bara is located along the White Lake, has 36 beds in 16 rooms and one suite. Within the hotel there is a restaurant with 100 seats and is divided into two parts ambient hunting and fishing adequately furnished and equipped.

Hotel "Tiski cvet" (***) is located in the center of Novi Bečej on the bank of yew, with 80 beds in single, double, triple rooms and suites. The rooms are equipped with TV and telephone equipment. In the hotel there is a restaurant with a summer terrace with 220 seats, cafe, bar and a travel agency. The hotel is located near the Cultural Center, a sports hall and outdoor sports.

"Kastel Banaterra" (***) in Nova Crnja renovated old building that still has rooms with TV, private bath with a total capacity of 40 beds, a restaurant with 150 seats and a summer garden. Although at this moment categorized with one star further plans of the castle will raise the standard and quality of service and therefore the category of the more stars.

Hotel "Crveni cvet" (**) is located in the center of Sečanj, capacity 52 beds, two four-bed apartments, apartments with 6 beds, 6 triple rooms, 4 double rooms with two single beds, 4 double rooms with a double bed and two single rooms. Within the hotel there is a snack bar, pub, restaurant with 220 seats and a banquet hall. All rooms and apartments are equipped with satellite TV, telephone and the Internet.

\section{THE POTENTIAL OF HUNTING TOURISM}

This chapter relates to the motive of hunting tourism, hunting and shooting games. What is important to note is that, in addition to evaluation of a game as a natural resource, we evaluate it through its sales, as opposed to other types of tourist movement in which the natural resources are framing and unfolding the tourism trends and satisfying tourist needs.

Hunting is a complex human activity, or activity of a particular social interest and importance in the function of the rational and sustainable hunting permeated with the spirit of humane and chivalrous attitude towards wildlife and nature in general, the purpose of which is carried out through the follow-up activities of the hunting economy (care, protection and use of wildlife and hunting area), scientific research and the protection / promotion of 
environmental hunting game (Prentović, 2006). Hunting as a special form of tourism includes moving and active staying of tourist-hunters in a specific environment-hunting area, as a part of a healthy natural environment, for hunting (hunting, capturing, viewing and recording) game, allowing its actors (hunters-tourists) to satisfy a strong motive (primarily a hobby and, for some people, even a passion). At the same time, they pay a fee for the shot game (trophies, meat, leather, etc...), accommodation and food and other related services, following the valid price lists (Prentović, 2005).

According to data from the Hunting Association of Vojvodina there are the following hunting associations in the Middle Banat "Zrenjanin" situated in Zrenjanin and managing the hunting ground "Begej", "Novi Bečej" from Novi Bečej managing the hunting ground "Jaruge", "Nova Crnja" from Nova Crnja that manages the hunting ground "Koštanac", "Žitište" from Žitište managing the hunting ground "Stari Begej" and "Sečanj" from Sečanj managing the hunting ground "Vučjak".

Table 1

Overview of the hunting ground of the Middle Banat with basic data and objects

\begin{tabular}{|c|c|c|c|c|c|c|c|c|c|}
\hline & \multirow{3}{*}{$\begin{array}{c}\text { Area/ } \\
\mathrm{Ha}\end{array}$} & \multirow{3}{*}{$\begin{array}{l}\text { Hunting } \\
\text { Area/ha }\end{array}$} & \multicolumn{7}{|c|}{ Objects in hunting areas } \\
\hline & & & \multirow[b]{2}{*}{$\begin{array}{l}\text { Hunting } \\
\text { Lodge }\end{array}$} & \multicolumn{2}{|c|}{ Feeding } & \multicolumn{2}{|c|}{$\begin{array}{c}\begin{array}{c}\text { Hunting } \\
\text { stand }\end{array} \\
\end{array}$} & \multirow[b]{2}{*}{$\begin{array}{c}\text { Waterholes } \\
\text { soloists }\end{array}$} & \multirow[b]{2}{*}{ Soloists } \\
\hline & & & & $\begin{array}{l}\text { Roe } \\
\text { deer }\end{array}$ & Pheasant & Stable & $\begin{array}{c}\text { In } \\
\text { a } \\
\text { tree }\end{array}$ & & \\
\hline Begej & 124,038 & 110,000 & 1 & 174 & 328 & 141 & 26 & 50 & 118 \\
\hline Jaruge & 60,745 & 58,988 & 4 & 266 & 245 & 9 & - & 19 & 237 \\
\hline Koštanac & 27,287 & 25,336 & 5 & 44 & 132 & 14 & 2 & 51 & 44 \\
\hline $\begin{array}{l}\text { Stari } \\
\text { Begej }\end{array}$ & 51,253 & 47,000 & 2 & 140 & 250 & 25 & 15 & 25 & 155 \\
\hline Vučjak & 52,268 & 47,248 & 7 & 75 & 155 & 23 & 18 & 56 & 62 \\
\hline Ukupno & 316,207 & 288,572 & 19 & 629 & 1110 & 212 & 61 & 201 & 616 \\
\hline
\end{tabular}

Note. Retrieved from The Hunting Association of Vojvodina.

Hunting Ground "Begej" is one of the largest in Serbia. The total hunting area is 124,038 ha, out of which the hunting area occupies 110,000 ha. The Association has 1,295 active fighters, owns 67.5 hectares of land, hunting lodge, 141 stable waiting stands, 26 tree stands, 174 for feeding deer, 328 feeding sites for small game, 6 shelters for pheasants, 118 soloists and 50 waterholes. Continuously cultivated game species are deer, wild boar, rabbit, pheasant and grey partridge (Poland). The developed hunting tourism activities can be allocated to the spring hunting deer, summer hunting quail, doves, autumn hunting of wild mallard and winter hunting of White-fronted geese. 
The Hunting Ground "Jaruge" area occupies 60,745 ha, out of which hunting area occupies 58,988 ha. The Association has 493 active hunters, owns 367 hectares of land, four hunters and two house hunting lodges, 9 stable waiting, 266 for feeding deer, 237 soloists, 19 waterholes, 245 for feeding pheasants and partridges and pheasants shelter for the area of 0.25 ha. Continuously cultivated game species are deer, wild boar, rabbit, pheasant and grey partridge (Poland). The developed hunting tourism activities can be allocated to the spring hunting deer, summer hunting quail, doves, autumn hunting rabbits and pheasants.

Hunting Ground "Koštanac" area is 27,287 ha, out of which hunting area covers 25,336 ha. The Association has 349 active hunters, owns 45 hectares of land, 5 hunting lodges, 14 stable waiting stands, two tree hunting stands, 44 for feeding deer, 44 soloists, 51 watering, 132 for feeding pheasants and partridges and shelter for pheasants area of 0.5 ha. Continuously cultivated game species are deer, rabbit, pheasant, grey partridge (Poland) and occasionally deer and wild boar. From developed hunting tourism activities are allocated to the spring hunting deer, summer hunting quail, doves, doves and wood pigeon.

Hunting Ground "Stari Begej" has an area 51,253 ha, of which hunting area covers 47,000 ha. The association owns 30 hectares of land, 25 stable waiting stands, 15 tree stands, 140 feeding stations for deer, 155 soloists, watering 25, 250 feeding the pheasants and partridges and 11 shelters for pheasants. Continuously cultivated game species are deer, rabbit, pheasant, grey partridge (Poland) and occasionally deer and wild boar. The developed hunting tourism activities are allocated to the spring hunting deer, summer hunting quail, doves, doves and wood pigeon, and autumn hunting rabbits and pheasants.

Table 2

Situation and shooting in municipal hunting societies in the Middle Banat in 2009 and 2010.

\begin{tabular}{cccccccc}
\hline Game I & & \multicolumn{2}{c}{ Roe deer } & \multicolumn{2}{c}{ Pheasant } & \multicolumn{2}{c}{ Rabbit } \\
\cline { 3 - 7 } Municipalities & & Condition & Hunted & Condition & Hunted & Condition & Hunted \\
\hline \multirow{2}{*}{ Nova Crnja } & 2009. & 1,370 & 179 & 2,000 & 1,719 & 9,310 & 2,380 \\
& 2010. & 1,380 & 167 & 2,290 & 773 & 6,120 & 2,206 \\
\multirow{2}{*}{ Novi Bečej } & 2009. & 5,273 & 426 & - & 1,920 & 13,872 & 2,171 \\
& 2010. & 5,088 & 633 & 5,800 & 1,474 & 5,273 & 2,413 \\
\multirow{2}{*}{ Sečanj } & 2009. & 1,380 & 41 & 4,800 & 1,930 & 7,876 & 1,094 \\
& 2010. & - & - & - & - & - & - \\
\multirow{2}{*}{ Zrenjanin } & 2009. & 2,999 & 151 & 7,500 & 2,729 & 14,600 & 3,074 \\
& 2010. & 2,950 & 158 & 7,500 & 2,114 & 7,000 & 2,272 \\
\multirow{2}{*}{ Žitište } & 2009. & 1,360 & 78 & 3,900 & 2,087 & 7,000 & 1,772 \\
& 2010. & 1,694 & 70 & 3,100 & 1,826 & 7,320 & 1,260 \\
\hline
\end{tabular}

Note. Retrieved from The Hunting Association of Vojvodina. 
Hunting Ground "Vučjak" occupies the total area of 52,268 ha, out of which hunting area covers 47,248 ha. The association owns 6 hectares of land, 7 hunting lodges, 23 stable waiting, 18 tree stands, 75 for feeding deer, 62 soloists, 56 watering, 155 for feeding pheasants and partridges and pheasants 9 shelters for a total area of 3.42 ha. Continuously cultivated game species are deer, rabbit, pheasant, grey partridge (Poland) and occasionally deer and wild boar. From developed hunting tourism activities stand out summer hunting quail, doves, doves and wood pigeon, autumn and winter wild mallard hunting and White-fronted geese.

Hunting tourism activity is tailored by its frequency in accordance with the strict hunting professional, ethical and legal standards relating to the manner of execution of the hunt. Hunting activities are clearly and precisely defined in terms of the hunting season and species. It is extremely important that the standards are respected in full, otherwise there could be a complete extinction of certain species.

\section{CONCLUSION}

Based on this work it can be concluded that there is a good basis for the development of hunting tourism in the Middle Banat. This basis is reflected in the well-organized and technically equipped hunting grounds, quality of game fund, an adequate database of accommodation facilities from which the greater part provides housing for the hounds, budget relief and surface waters. In addition to these benefits, this kind of tourism activities must be implemented in compliance with the laws and regulations that govern because it involves the use of firearms, which can sometimes lead to serious injury or death. Therefore, service providers, guides and gamekeepers should be maximally professional and trained to keep the negative consequences to a minimum. Also, their important task and the problem are the poachers who have a very negative effect on the game.

In addition, as some of the problems of development and improvement of hunting tourism are distinguished by inadequate infrastructural equipment of (cold meat), legal proceedings for the transport of meat to tourists' home or place of sale, insufficient activity of service providers in terms of marketing and promotion. The above-mentioned problems are solvable if we show a willingness to overcome the local to the national level of government, but most of all, it is necessary to recognize the benefits of hunting tourism, both for the local population, and the Middle Banat. 
67 | POTENTIAL OF HUNTING TOURISM IN THE MIDDLE BANAT

\section{REFERENCES}

Bogdanović, Ž., \& Marković, S. (2005). Vode Banata. Novi Sad: PMF, Institut za geografiju.

Grupa autora. (1993). Specijalni rezervat prirode „Stari Begej-Carska bara“. Novi Sad: Pokrajinski zavod za zaštitu prirode.

Lazić, L., \& Pavić, D. (2003). Klima Banata. Novi Sad: PMF, Institut za geografiju.

Mrkša, M.M. (2008). Turistička valorizacija specijalnih rezervata prirode Vojvodine. Beograd: Srpsko geografsko društvo.

Mrkša, M. (2009). Stanje i perspektive razvoja turizma Srednjeg Banata u kontekstu održivog razvoja. Novi Sad: PMF, Depatman za geografiju, turizam i hotelijerstvo.

Prentović, R. (2005). Lovni turizam - skripta. Novi Sad: PMF - Departman za geografiju, turizam i hotelijerstvo.

Prentović, R. (2006). Osnovi lovstva. Novi Sad: PMF - Departman za geografiju, turizam i hotelijerstvo.

Prentović, R., Kurjački, A., \& Cvijanović, D. (2012). Hunting in rural areas of Bačka. Ekonomika poljoprivrede, IAE Belgrade, 59(3), 385-400.

The Hunting Association of Vojvodina.

Received: 18.02.2015. Accepted: 07.04.2015. 